\title{
The effects of herbal teas on drug permeability
}

\author{
Akira Nakatsuma, Satoshi Wada, Junji Kamano, Yoshimitsu Kiriyama, Katsuhito Kino, and Masaki Ninomiya* \\ Kagawa School of Pharmaceutical Sciences, Tokushima Bunri University, Japan
}

\begin{abstract}
Herbal teas such as those made from Houttuynia cordata have been consumed for generations for health promotion. Herbal teas contain many ingredients, and there is concern that herbal teas can affect the pharmacokinetics of drugs. In this study we examined the effect of herbal teas on drug permeability. We used the human colon carcinoma cell line Caco-2 as a model to study the permeability of two drugs across the intestinal cell membrane. We quantified of the amount of digoxin and verapamil passed from apical to basal membranes of Caco-2 cells with and without extracts $(1 \mathrm{mg} / \mathrm{mL} \mathrm{or} 10 \mathrm{mg} / \mathrm{mL})$ of four different teas (Rubus suavissimus S. Lee, Ginkgo biloba, Houttuynia cordata, and Eucommia ulmoides). These extracts were made with hot water and dried. For our experiments, the dried extracts were resuspended in water. Our results showed that extracts from Rubus suavissimus S. Lee, Houttuynia cordata, and Eucommia ulmoides at a concentration of $1 \mathrm{mg} / \mathrm{mL}$ or $10 \mathrm{mg} / \mathrm{mL}$ did not affect digoxin permeability from apical to basal membranes of Caco-2 cells. However, an extract from Ginkgo biloba at a concentration of $10 \mathrm{mg} /$ $\mathrm{mL}$ significantly increased permeability of digoxin and verapamil. Though this concentration is higher than that of typical tea preparations, Ginkgo biloba extract may exert this effect by inhibiting drug export $\mathrm{P}$-glycoprotein $(\mathrm{P}-\mathrm{gp})$ since both digoxin and verapamil are known to be transported by $\mathrm{P}$-gp.
\end{abstract}

\section{Introduction}

In developed countries, the incidence of lifestyle diseases has risen. Increasing interest in health promotion is reflected in rising sales of functional foods and supplements. The global market for vitamin and mineral supplements and functional foods was estimated in 2011 to be worth approximately USD 25.3 billion [1]. Although the majority of supplement sales were those of vitamins and minerals, a large proportion are functional supplements containing herbs. Herbal teas have been consumed traditionally for protection against disease. The efficacy and effectiveness of ingredients of the herbal teas have been extensively studied, and the effectiveness of herbal teas on hypertension [2], inflammation [3,4], allergies [5], and improvements of brain activity [6] has been documented.

Use of herbal teas for the general purpose of health maintenance does not seem to pose health risks, but concern has arisen regarding potential drug interactions with consumption of herbal teas [7]. It has been reported that more than $80 \%$ of patients take some kind of supplements, with half of those taking supplements other than vitamins and minerals [8]. Potential interactions between supplements and drugs have not been adequately studied [9].

Herbal teas contain medicinal compounds that could interact with other medicines. For example, some herbal medicines contain furanocoumarin that inhibits P-glycoprotein (P-gp), which exports drugs from cells. Furanocoumarin also inhibits cytochrome P450 (CYP) 3A4, a metabolic enzyme. Furanocoumarin affects the pharmacokinetics parameter of P-gp substrate drugs [10]. It has been shown that licorice root, commonly used as a sweetener, also inhibits P-gp $[11,12]$.

In this study, we investigated the effects of extracts of Ginkgo bioba, Eucommia ulmoides, Houttuynia cordata, and Rubus suavissimus S. Lee on the permeability of the drugs digoxin and verapamil using the human colon carcinoma cell line Caco-2 as a model of intestinal absorption of drugs.

\section{Materials and methods}

\section{Materials}

Digoxin and verapamil were obtained from SIGMA-ALDRICH (St. Louis, MO, USA) and Wako (Osaka, Japan), respectively. Dried products (3-5 g) in tea Ginkgo biloba (Kenko Foods, Yokohama, Japan), Eucommia ulmoides (Kobayashi Pharmaceuticals, Osaka, Japan), Houttuynia cordata (Honzo, Nagoya, Japan), or Rubus suavissimus S. Lee (Honzo, Nagoya, Japan) were extracted by incubation with 500 $\mathrm{mL}$ of boiling water at $100{ }^{\circ} \mathrm{C}$ for $5 \mathrm{~min}$. The extracts were vacuumconcentrated to a volume of $20 \mathrm{~mL}$, and $1 \mathrm{~mL}$ of each vacuumconcentrated solution was evaporated to dryness. The evaporation residue was weighed to calculate the concentrations of extracts of herbal teas. The vacuum-concentrated extracts of each herbal tea was prepared to be $1 \mathrm{mg} / \mathrm{mL}$ or $10 \mathrm{mg} / \mathrm{mL}$ in Hanks' balanced salt solution containing $10 \mathrm{mM}$ HEPES (pH 7.4) (Figures 1 and 2).

\section{Cell culture}

Cultures of the human colon carcinoma cell line Caco-2 were obtained from ATCC (Manassas, VA, USA) and were maintained in DMEM supplemented with $10 \% \mathrm{FBS}, 100$ units/mL penicillin, and 100 $\mu \mathrm{g} / \mathrm{mL}$ streptomycin at $37^{\circ} \mathrm{C}$ under $5 \% \mathrm{CO}_{2}$. To form a monolayer of CaCo- 2 cells, $1 \times 10^{5}$ cells were plated into 12 -well Transwell plates with pore size of $3.0 \mu \mathrm{m}$ (Corning, Corning, NY, USA) for 21 days at $37^{\circ} \mathrm{C}$ under $5 \% \mathrm{CO}_{2}$. The culture medium was changed every $2-3$ days.

Correspondence to: Masaki Ninomiya, Professor, Kagawa School of Pharmaceutical Sciences, Tokushima Bunri University, 1314-1, Shido, Sanuki, Kagawa 769-2193, Japan, Tel: +81-87-899-7426; Fax: +81-87-894-0181; E-mail: m-nino@kph.bunri-u.ac.jp

Key words: P-glycoprotein, verapamil, digoxin, ginkgo biloba, eucommia ulmoides, houttuynia cordata, rubus suavissimus S. Lee

Received: November 17, 2015; Accepted: December 3, 2015; Published: December 07, 2015 


\section{Quantifications of digoxin and verapamil}

Digoxin (final conc. $2 \mu \mathrm{M}$ ) or verapamil (final conc. $20 \mu \mathrm{M}$ ) was added to the apical chamber in the absence or presence of herbal tea extract. After $2 \mathrm{~h}, 1 \mathrm{~mL}$ of the medium from the basal chamber was collected. $0.5 \mathrm{~mL}$ of $200 \mathrm{mM}$ phosphate buffer (pH 9.3) and $1 \mathrm{~mL}$ of an ethyl acetate/hexane/dichloromethane $(3: 1: 1, \mathrm{v} / \mathrm{v})$ mixture were added. After 10 minutes of shaking, samples were centrifuged $(10,000 \times \mathrm{g}$, $4^{\circ} \mathrm{C}, 10$ minutes). A volume of $0.5 \mathrm{~mL}$ of the upper organic layer was transferred to a tube and evaporated to dryness under airflow at $40^{\circ} \mathrm{C}$. The evaporated residues were dissolved in $100 \mu \mathrm{L}$ of water/ $\mathrm{CH}_{3} \mathrm{CN}$ $(7: 3, \mathrm{v} / \mathrm{v})$ mixture and used as samples for HPLC quantification.

Digoxin (Figure 1) was quantified by HPLC (Shimazu, SPD$\mathrm{M} 20 \mathrm{~A}$ ) with a $100 \mathrm{~mm} \times \varphi 4.6 \mathrm{~mm}, 3 \mu \mathrm{m}$ ODS column (Unison UKC18, Imtakt) with a flow rate of $0.8 \mathrm{~mL} / \mathrm{min}$ using water/ $\mathrm{CH}_{3} \mathrm{CN}$ (7:3); absorbance at $220 \mathrm{~nm}$ was monitored. Verapamil (Figure 2) was quantified by HPLC with a flow rate of $1.0 \mathrm{~mL} / \mathrm{min}$ using $100 \mathrm{mM}$ $\mathrm{AcONH}_{4} / \mathrm{CH}_{3} \mathrm{CN}$ (6:4); absorbance at $235 \mathrm{~nm}$ was monitored.

\section{Statistical analysis}

Results of multiple observations are presented as means \pm SEM. One-way analysis of variance (ANOVA) followed by the Williams' test was used for multiple comparisons. $p<0.05$ was considered significant.

\section{Results}

We evaluated the effects of extracts of herbal teas on drug permeability using Caco-2 cell monolayers from the intestinal tract. We examined the effects of each tea on the transport by P-gp by measuring the amount of digoxin and verapamil that crossed the treated monolayer.
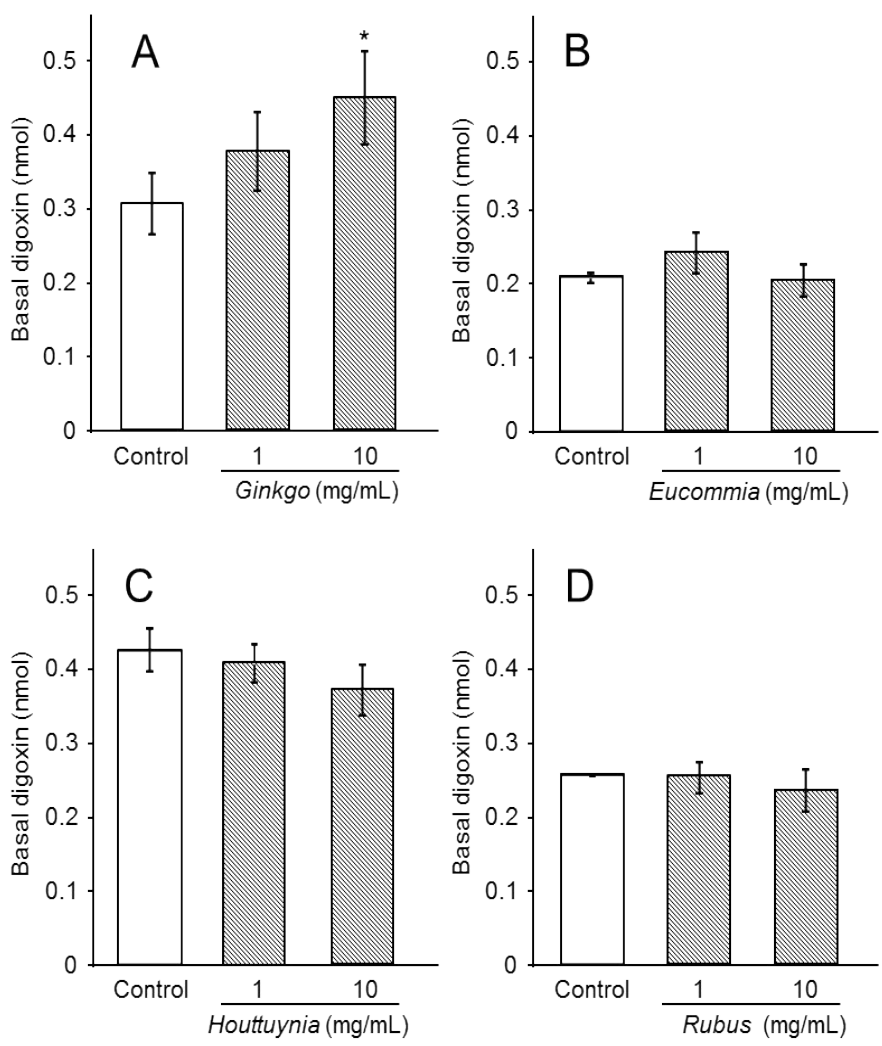

Figure 1. Effect of herbal tea extracts on digoxin permeability. Values are mean \pm S.E. $\mathrm{n}=4$ for each treatment. Significant difference $(*: p<0.05$ vs control, Williams' test)

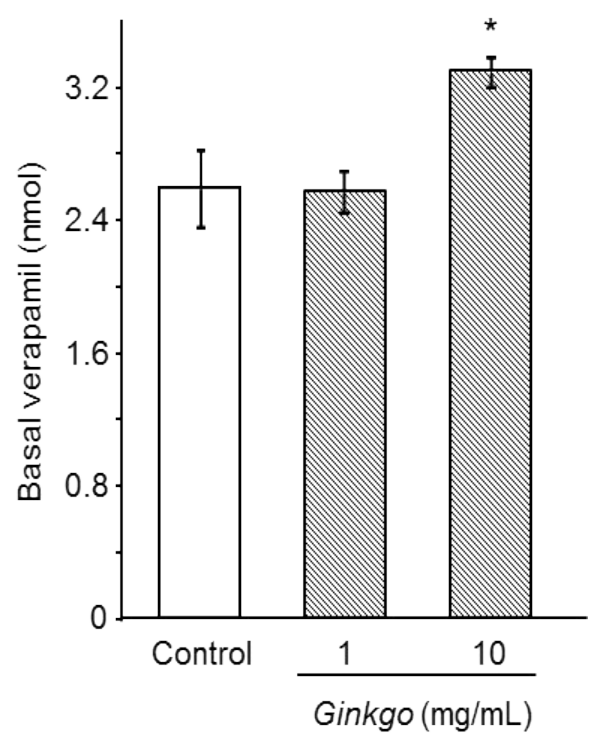

Figure 2. Effect of Ginkgo biloba extract on verapamil permeability. Values are mean \pm S.E. $\mathrm{n}=3$ for each treatment. Significant difference $(*: p<0.05$ vs control, Williams' test $)$

First, we examined the effects of herbal tea extracts on digoxin permeability from the apical side to the basal side of the Caco- 2 cell monolayer. The concentration of each concentrated extract was as follows: Ginkgo biloba, $90 \mathrm{mg} / \mathrm{mL}$; Eucommia ulmoides, $30 \mathrm{mg} / \mathrm{mL}$; Houttuynia cordata, $50 \mathrm{mg} / \mathrm{mL}$; Rubus suavissimus S. Lee, $50 \mathrm{mg} / \mathrm{mL}$. Digoxin (1.0 nmol) alone or in combination with $1 \mathrm{mg} / \mathrm{mL}$ or $10 \mathrm{mg} /$ $\mathrm{mL}$ of the Ginkgo biloba, Eucommia ulmoides, Houttuynia cordata, or Rubus suavissimus $\mathrm{S}$. extracts was added to the buffer on the apical side. The amount of digoxin transported to the basal side was quantified (Figure 1): digoxin alone, $0.33 \mathrm{nmol}$ (33.3\%); digoxin with $1 \mathrm{mg} / \mathrm{mL}$ of an extract of Ginkgo biloba, $0.39 \mathrm{nmol}$ (39.3\%); digoxin with $10 \mathrm{mg} /$ $\mathrm{mL}$ of an extract of Ginkgo biloba, $0.47 \mathrm{nmol}$ (46.5\%) (Figure 1A). Thus Ginkgo biloba increased digoxin permeability in a dose-dependent manner. However, the other three kinds of teas did not significantly affect digoxin transport (Figure 1B, C, D).

We also investigated the effect of Ginkgo biloba extract on verapamil transport. Verapamil $(10 \mathrm{nmol})$ alone or in combination with $1 \mathrm{mg} / \mathrm{mL}$ or $10 \mathrm{mg} / \mathrm{mL}$ of Ginkgo biloba extract was added to the buffer solution on the apical side, and then the amount of verapamil transported to the basal side was quantified (Figure 2). The quantities of verapamil in the basal side were as follows: verapamil alone, $2.65 \mathrm{nmol}(26.5 \%)$; verapamil with $1 \mathrm{mg} / \mathrm{mL}$ of Ginkgo biloba extract, $2.63 \mathrm{nmol}(26.3 \%)$; verapamil with $10 \mathrm{mg} / \mathrm{mL}$ of Ginkgo biloba extract, $3.37 \mathrm{nmol}(33.7 \%)$. Verapamil transport was significantly increased in the presence of 10 $\mathrm{mg} / \mathrm{mL}$ of Ginkgo biloba extract.

\section{Discussion}

Findings regarding interactions between functional foods and medicines will be dependent on each medicine. For example, approximately 40 functional foods modulate the effects of warfarin [13]. However, the information available regarding interactions between functional foods and medicines is limited [14]. To our knowledge, medical manuals rarely mention foods that can interact with medicines, other than the well-documented examples of grapefruit juice (GFJ) $[15,16]$ and St. John's wort (Hypericum perforatum.) [17]. Among four 
kinds of teas used in this study, only Ginkgo biloba has been reported to interact with medicines [18].

The concentrations of extracts for normal drinking is $1.2-3.6 \mathrm{mg} /$ $\mathrm{mL}$, thus the effective concentration of extracts used in this study, $10 \mathrm{mg} / \mathrm{mL}$ (Figure 1), is 2.8-8.3 times higher than the concentration of extracts consumed in normal tea drinking. Eucommia ulmoides, Houttuynia cordata, and Rubus suavissimus S. Lee did not significantly affect the levels of digoxin transport from apical to basal membranes (Figure 1B, C, D). Therefore, our results show that consumption of herbal tea prepared in normal concentrations should not affect the transport of drugs by P-gp.

In contrast, Ginkgo biloba extract increased digoxin permeability from the apical to basal membrane in a dose-dependent manner (Figure 1A). Ginkgo biloba extract also increased verapamil permeability (Figure 2). Thus, Ginkgo biloba extract may exert this effect by inhibiting export by P-gp on the apical side. These results are in accord with those of Wang et al. [19], who showed that flavonoids in Ginkgo biloba inhibited the function of P-gp [19]. The effect of Ginkgo biloba extract on P-gp may be negligible, because the effective concentration $(10 \mathrm{mg} / \mathrm{mL})$ is greater than the concentration $(3.6 \mathrm{mg} / \mathrm{mL})$ of typical tea preparations.

Inhibition and induction of the metabolic enzyme CYP can also affect the pharmacokinetics of treatment with these medications. This should be of concern since CYP3A4 is associated with the metabolism of many drugs. It is well known that there is overlap in the substrate specificities of CYP3A4 and P-gp [20]. Thus, substrates of P-gp might significantly affect pharmacokinetics. GFJ affects the function of CYP3A4 and P-gp [16]. In addition, catechins in green tea (Camellia sinensis) affect the function of CYP3A4 and P-gp in vitro [21]. Moreover, it has been reported that an extract of Ginkgo biloba inhibited the function of CYP3A4 and P-gp [19, 22]. However, a clinical study in Korea has shown that pharmacokinetics of cilostazol was not affected significantly when used with Ginkgo biloba [23]. In addition, herbs are used as alternative medicine in $30-70 \%$ of patients treated for cancer in Germany, and it has been evaluated that Ginkgo biloba can be used with drugs safely [24]. Thus, the foods that contain ingredients that can inhibit metabolic enzymes and/or drug transport proteins in vitro may not affect pharmacokinetics.

It is necessary to examine the effects of the chronic intake of functional foods, even if single consumption does not affect pharmacokinetic parameters. For example, dietary supplement ingredients to rats for four weeks affected the maximum concentration in blood digoxin levels $\left(\mathrm{C}_{\max }\right)$ and the area under the blood concentrationtime curve (area under the curve, AUC) [25]. It has been reported that chronic exposure of cancer cells to kaempferol significantly increased glutathione $S$-transferase activity and reduced the effect of anticancer agents, although this was an in vitro study [26].

In conclusion, since the concentrations of tea extracts $(10 \mathrm{mg} / \mathrm{mL})$ used in this study were 2.8-8.3 times higher than the concentration for normal drinking, the effects of these four teas on the absorption of drugs can be disregarded. However, it is still important to examine the effects of chronic intake of herbal teas on both pharmacokinetics and effects of drugs in vivo.

\section{References}

1. Key players in the global functional food industry. 4th edition 2012.
2. Luo LF, Wu WH, Zhou YJ, Yan J, Yang GP, et al. (2010) Antihypertensive effect of Eucommia ulmoides Oliv. extracts in spontaneously hypertensive rats. $J$ Ethnopharmacol 129: 238-243. [Crossref]

3. Li W, Zhou P, Zhang Y, He L (2011) Houttuynia cordata, a novel and selective COX-2 inhibitor with anti-inflammatory activity. J Ethnopharmacol 133: 922-927. [Crossref]

4. Lu HM, Liang YZ, Yi LZ, Wu XJ (2006) Anti-inflammatory effect of Houttuynia cordata injection. J Ethnopharmacol 104: 245-249. [Crossref]

5. Ono Y (2004) Anti-inflammatory and anti-allergic effects of Tiencha (Rubus suavissimus S. Lee) Allergy in Practice $317: 380-385$.

6. Silberstein RB, Pipingas A, Song J, Camfield DA, Nathan PJ, et al. (2011) Examining brain-cognition effects of ginkgo biloba extract: brain activation in the left temporal and left prefrontal cortex in an object working memory task. Evid Based Complement Alternat Med 164139. [Crossref]

7. Fugh-Berman A (2000) Herb-drug interactions. Lancet 355: 134-138. [Crossref]

8. Young LA, Faurot KR, Gaylord SA (2009) Use of and communication about dietary supplements among hospitalized patients. J Gen Intern Med 24: 366-369. [Crossref]

9. Végh A, Lankó E, Fittler A, Vida RG, Miseta I, et al. (2014) Identification and evaluation of drug-supplement interactions in Hungarian hospital patients. Int J Clin Pharm 36: 451-459. [Crossref]

10. Iwanaga K, Arimune K, Miyazaki M, Shibano M, Taniguchi M, et al. (2012) Effects of furanocoumarins in Kampo extract-based medicines on rat intestinal absorption of CYP3A and P-glycoprotein substrate drugs in vivo. Arch Pharm Res 35: 1055-1064. [Crossref]

11. Yoshida N, Koizumi M, Adachi I, Kawakami J (2006) Inhibition of P-glycoproteinmediated transport by terpenoids contained in herbal medicines and natural products. Food Chem Toxicol 44: 2033-2039. [Crossref]

12. Satoh T, Watanabe Y, Ikarashi N, Ito K, Sugiyama K (2009) Effects of Kampo medicines on P-glycoprotein. Biol Pharm Bull 32: 2018-2021. [Crossref]

13. Heck AM, DeWitt BA, Lukes AL (2000) Potential interactions between alternative therapies and warfarin. Am J Health Syst Pharm 57: 1221-1227. [Crossref]

14. Asahina Y, Hori S, Ohtana H, Sawada Y (2009) Questionnaire Survey on Clinica Performance of Pharmacists Concerning Patients' Use of Herbs and Dietary Supplements. Jpn J Pharm Health Care Sci 35: 685-692.

15. Becquemont L, Verstuyft C, Kerb R, Brinkmann U, Lebot M, et al. (2001) Effect of grapefruit juice on digoxin pharmacokinetics in humans. Clin Pharmacol Ther 70: 311 316. [Crossref]

16. Kane GC, Lipsky JJ (2000) Drug-grapefruit juice interactions. Mayo Clin Proc 75 933-942. [Crossref]

17. Shibayama Y, Ikeda R, Motoya T, Yamada K (2004) St. John's Wort (Hypericum perforatum) induces overexpression of multidrug resistance protein 2 (MRP2) in rats: a 30-day ingestion study. Food Chem Toxicol 42: 995-1002. [Crossref]

18. Hellum BH, Nilsen OG (2008) In vitro inhibition of CYP3A4 metabolism and P-glycoprotein-mediated transport by trade herbal products. Basic Clin Pharmacol Toxicol 102: 466-475. [Crossref]

19. Wang Y, Cao J, Zeng S (2005) Involvement of P-glycoprotein in regulating cellular levels of Ginkgo flavonols: quercetin, kaempferol, and isorhamnetin. $J$ Pharm Pharmacol 57: 751-758. [Crossref]

20. Wacher VJ, Wu CY, Benet LZ (1995) Overlapping substrate specificities and tissue distribution of cytochrome P450 3A and P-glycoprotein: implications for drug delivery and activity in cancer chemotherapy. Mol Carcinog 13: 129-34. [Crossref]

21. Misaka S, Kawabe K, Onoue S, Werba JP, Giroli M, et al. (2013) Effects of green tea catechins on cytochrome P450 2B6, 2C8, 2C19, 2D6 and 3A activities in human liver and intestinal microsomes. Drug Metab Pharmacokinet 28: 244-249. [Crossref]

22. Hellum BH, Nilsen OG (2008) In vitro inhibition of CYP3A4 metabolism and P-glycoprotein-mediated transport by trade herbal products. Basic Clin Pharmacol Toxicol 102: 466-475. [Crossref]

23. Kim HS, Kim GY, Yeo CW, Oh M, Ghim JL, et al. (2014) The effect of Ginkgo biloba extracts on the pharmacokinetics and pharmacodynamics of cilostazol and its active metabolites in healthy Korean subjects. Br J Clin Pharmacol 77: 821-830. [Crossref]

24. Haefeli WE, Carls A (2014) Drug interactions with phytotherapeutics in oncology. Expert Opin Drug Metab Toxicol 10: 359-377. [Crossref] 
25. Higashi K, Tanaka C, Imanishi K, Sawamoto K, Horikawa T, et al. (2013) Influence of long-term enteral nutrition on pharmacokinetics of digoxin in rats. Drug Metab Pharmacokinet 28: 44-52. [Crossref]
26. Nakatsuma A, Fukami T, Suzuki T, Furuishi T, Tomono K, et al. (2010) Effects of kaempferol on the mechanisms of drug resistance in the human glioblastoma cell line T98G. Pharmazie 65: 379-383. [Crossref]

Copyright: $\bigcirc 2015$ Nakatsuma A. This is an open-access article distributed under the terms of the Creative Commons Attribution License, which permits unrestricted use, distribution, and reproduction in any medium, provided the original author and source are credited. 